\title{
Salinity and flow rates of nutrient solution on cauliflower biometrics in NFT hydroponic system
}

\author{
Hammady R. e Soares ${ }^{1}$, Ênio F. de F. e Silva ${ }^{1}$, Gerônimo F. da Silva ${ }^{1}$, Adiel F. da S. Cruz ${ }^{1}$,
} José A. Santos Júnior ${ }^{1} \&$ Mário M. Rolim ${ }^{1}$

\begin{abstract}
${ }^{1}$ Universidade Federal Rural de Pernambuco/Departamento de Engenharia Agrícola, Recife, PE, Brasil. E-mail: hresoares@hotmail.com (Corresponding author) - ORCID:0000-0003-3475-3417; effsilva@uol.com.br - ORCID: 0000-0002-8652-503X; agrogefe@yahoo.com.br - ORCID: 0000-0002-33487252; felipe.adiel@gmail.com - ORCID: 0000-0002-1182-3817; eng.amiltonjr@hotmail.com - ORCID: 0000-0002-1656-7103; mario.rolim@ufrpe.br
\end{abstract} - ORCID: 0000-0003-2111-3875

\begin{abstract}
The use of brackish water in hydroponic crops represents an alternative for vegetable production. In this context, two experiments were conducted to evaluate the effect of using brackish water to prepare the nutrient solution and replace the evapotranspired depth, applied at different flow rates, on cauliflower biometrics in NFT (nutrient film technique) hydroponic system. In both experiments, the experimental design was completely randomized with four repetitions, in a $6 \times 2$ factorial scheme: six levels of water electrical conductivity $(\mathrm{ECw})$ in interaction with two flow rates of nutrient solution application in the hydroponic channels (1.5 and 2.5 $\left.\mathrm{L} \mathrm{min}^{-1}\right)$. In Experiment I, brackish waters with different EC (1.5, 2.5, 3.5, 4.5 and 5.5 dS m $\left.\mathrm{m}^{-1}\right)$, obtained by the addition of $\mathrm{NaCl}$ in public-supply water $\left(0.2 \mathrm{dS} \mathrm{m}^{-1}\right)$, were used. In Experiment II, the chemical characteristics of brackish waters collected in the semiarid region of Pernambuco were simulated, with EC of $1.67,3.30,4.71,5.88$ and $13.84 \mathrm{dS} \mathrm{m}^{-1}$, plus the control $\left(0.2 \mathrm{dS} \mathrm{m}^{-1}\right)$. Increasing salinity reduced cauliflower growth. Flow rate of $1.5 \mathrm{~L} \mathrm{~min}^{-1}$ promoted the best results of shoot fresh and dry masses, leaf area, number of leaves, plant height and shoot diameter. The best water for cauliflower production was publicsupply water and, among the well waters, the best was the calcium sulfate-rich water with EC of $1.67 \mathrm{dS} \mathrm{m}$.
\end{abstract}

Key words: Brassica oleracea var. botrytis L., hydroponics, horticulture, brackish water

\section{Salinidade e vazões da solução nutritiva na biometria de couve-flor cultivada em sistema hidropônico NFT}

RESUMO: O uso de águas salobras em cultivos hidropônicos representa uma alternativa para a produção de hortaliças. Assim, foram conduzidos dois experimentos objetivando avaliar o uso de águas salobras, no preparo da solução nutritiva e reposição da lâmina evapotranspirada aplicadas em diferentes vazões na biometria de plantas de couve-flor em sistema hidropônico NFT (técnica do fluxo laminar de nutrientes). Nos dois experimentos, o delineamento experimental utilizado foi o inteiramente casualizado com quatro repetições, em esquema fatorial $6 \times 2$ : seis níveis de condutividade elétrica da água (CEa) em interação com duas vazões de aplicação da solução nutritiva nos canais hidropônicos $\left(1,5\right.$ e $\left.2,5 \mathrm{~L} \mathrm{~min}^{-1}\right)$. No Experimento I utilizaram-se águas salobras com diferentes $\mathrm{CE}\left(1,5 ; 2,5 ; 3,5 ; 4,5\right.$ e 5,5 dS m $\left.\mathrm{d}^{-1}\right)$, obtidos a partir da adição de $\mathrm{NaCl}$ na água de abastecimento $\left(0,2 \mathrm{dS} \mathrm{m}^{-1}\right)$. No Experimento II foram simuladas as características químicas das águas salobras coletadas na região semiárida de Pernambuco, com CE de 1,67; 3,30; 4,71; 5,88 e 13,84 dS m-1, além do controle $\left(0,2 \mathrm{dS} \mathrm{m}^{-1}\right)$. O aumento da salinidade reduziu o crescimento da couve-flor. A vazão de $1,5 \mathrm{~L} \mathrm{~min}^{-1}$ foi a que proporcionou os melhores resultados para as massas fresca e seca da parte aérea, área foliar, número de folhas, altura de planta e diâmetro da parte aérea. A melhor água para a produção da couve-flor foi a de abastecimento e dentre as de poços, a melhor foi a água sulfatada cálcica de 1,67 $\mathrm{dS} \mathrm{m}^{-1}$.

Palavras-chave: Brassica oleracea var. botrytis L., hidroponia, horticultura, águas salobras 


\section{INTRODUCTION}

The feasibility of using brackish waters to grow different leafy vegetables, especially in the context of hydroponic cultivation, is related to the absence of action of the matric potential, which has been widely proven by several studies (Soares et al., 2015; Cruz et al., 2018; Lira et al., 2018).

In the context of the Brazilian semiarid region, brackish waters from wells have distinct natures and concentrations, which in turn influence plant development differently. Therefore, this understanding is of fundamental importance for the use of brackish waters in hydroponic crops (Silva et al., 2018).

One of the problems encountered by producers in the NFT (nutrient film technique) system is the increase in nutrient solution temperature, which reduces the amount of dissolved oxygen for plants (Bremenkamp et al., 2012). In these cases, the increase in flow rate can provide lower temperatures during the hottest hours of the day, leading to lower effect of heat exchange on plants (Genuncio et al., 2011).

Cauliflower (Brassica oleracea var. botrytis L.) is classified as moderately tolerant to salinity, and the effects of salinity on the biometrics of plants indicates that salinity tolerance is variable among species and dependent on environmental factors (Oliveira et al., 2014; Giuffrida et al., 2016). However, the literature evidencing the joint effect of salinity and flow rates of nutrient solution application on cauliflower in NFT hydroponic system is still scarce.

In view of the above, the objective of this study was to identify and characterize any differences in the response of cauliflower plants exposed to the use of brackish waters of different natures and salt concentrations in the preparation of nutrient solutions applied at different flow rates.

\section{Material ANd Methods}

The study was conducted in the Agricultural Engineering Department of the Universidade Federal Rural de Pernambuco (UFRPE), in a protected environment (greenhouse), with the following dimensions: $7.0 \mathrm{~m}$ wide, $24.0 \mathrm{~m}$ long, $3.0 \mathrm{~m}$ ceiling right and $4.5 \mathrm{~m}$ at the highest part of the greenhouse, whose structure is located at the geographical coordinates $8^{\circ} 1^{\prime} 5^{\prime \prime} \mathrm{S}$ and $34^{\circ} 5^{\prime} 48^{\prime \prime} \mathrm{W}$, with an altitude of $6.5 \mathrm{~m}$.

In both experiments, the experimental design used was completely randomized with four repetitions, in a $6 \times 2$ factorial scheme: six values of water electrical conductivity $(\mathrm{ECw})$ in interaction with two flow rates of nutrient solution application in the hydroponic channels ( 1.5 and $\left.2.5 \mathrm{~L} \mathrm{~min}^{-1}\right)$.

In Experiment I, with temperature and air relative humidity averages of $35^{\circ} \mathrm{C}$ and $85 \%$, cauliflower plants of the cv. 'Piracicaba Precoce' were exposed to nutrient solutions prepared and replaced using brackish waters with EC of 1.5, $2.5,3.5,4.5$ and $5.5 \mathrm{dS} \mathrm{m}^{-1}$, obtained by the addition of $\mathrm{NaCl}$ to public-supply water $\left(0.2 \mathrm{dS} \mathrm{m}^{-1}\right)$.

In Experiment II, in which temperature and air relative humidity averages of $33^{\circ} \mathrm{C}$ and $80 \%$ were recorded, cauliflower plants of the cv. 'Sarah 1169' were also exposed to nutrient solutions prepared and replaced with brackish waters simulating the chemical characteristics of the waters collected in the semiarid region of Pernambuco, Brazil, with EC of 1.67, 3.30, 4.71, 5.88 and $13.84 \mathrm{dS} \mathrm{m}^{-1}$, plus a control $\left(0.2 \mathrm{dS} \mathrm{m}^{-1}\right)$. The proportion and concentration of salts used to simulate the brackish waters (Table 1) coincided with those of water samples collected in wells installed in the Moxotó River Basin, specifically in the municipality of Ibimirim, PE, Brazil, and properly characterized.

The hydroponic system adopted in both experiments was the Nutrient Film Technique - NFT, which consisted of independent trapezoidal profiles, with $3 \mathrm{~m}$ length (commercial diameter of $150 \mathrm{~mm}$ ), which were installed at spacing of 0.50 $\mathrm{m}$ between plants and $0.60 \mathrm{~m}$ between profiles, at a maximum height of $1.10 \mathrm{~m}$ in relation to the lower reference plane with $3.33 \%$ slope. Each plot also had a $32-\mathrm{W}$ electric circulation pump, a 50-L reservoir for nutrient solution and a $15-\mathrm{L}$ automatic supply reservoir to replenish the level of the nutrient solution reservoir, which decreases as water is consumed by plants (Soares et al., 2009).

The seedlings used in both experiments were produced in a 200-cell tray, filled with coconut fiber and irrigated with $100 \mathrm{~mL}$ of nutrient solution consisting of $50 \%$ of the fertilizer quantity recommended by Furlani (1998), applied twice a day, in the morning and afternoon. The seedlings were transplanted to the hydroponic system and the treatments began to be applied at 30 days after sowing (DAS).

The fertilizers used were calcium nitrate, potassium nitrate, monoammonium phosphate (MAP), magnesium sulfate, copper sulfate, zinc sulfate, manganese sulfate, boric acid, sodium molybdate and Fe-EDTA-13\%. When necessary, the nutrient solution $\mathrm{pH}$ was adjusted by adding $\mathrm{KOH}$ or $\mathrm{HNO}_{3}$, aiming to keep it within the range from 5.0 to 6.5. The nutrient solution was monitored by readings of $\mathrm{pH}$ and ECsol on alternate days throughout the cultivation cycle (49 DAT for $\mathrm{cv}$. Piracicaba recoce' and 60 DAT for cv. Sarah 1169).

The application of the nutrient solution in the channels, also in both experiments, and respecting the application flow rates, was controlled by a mechanical timer programmed to perform nutrient solution circulation events every $15 \mathrm{~min}$. At night time, the timer was programmed to circulate the solution every $2 \mathrm{~h}$ for $15 \mathrm{~min}$.

Table 1. Chemical composition of groundwater collected in the semiarid region of Pernambuco, Brazil, and used to prepare the nutrient solution and replace the evapotranspired depth

\begin{tabular}{|c|c|c|c|c|c|c|c|c|c|c|}
\hline \multirow{2}{*}{ Wells } & \multirow{2}{*}{$\begin{array}{c}E C \\
\left(\mathrm{dS} \mathrm{m}^{-1}\right)\end{array}$} & \multirow[b]{2}{*}{$\mathrm{pH}$} & $\mathrm{Ca}^{++}$ & $\mathrm{Mg}^{++}$ & $\mathrm{K}^{+}$ & $\mathrm{Na}^{+}$ & $\mathrm{Cr}$ & $\mathrm{CO}_{3}{ }^{2-}$ & $\mathrm{HCO}_{3}{ }^{\circ}$ & $\mathrm{SO}_{4}{ }^{2-}$ \\
\hline & & & \multicolumn{8}{|c|}{$\left(\mathrm{mg} \mathrm{L}^{-1}\right)$} \\
\hline W1 & 1.67 & 7.23 & 90.09 & 71.66 & 2.73 & 176.86 & 349.70 & 52.85 & 361.24 & 133.40 \\
\hline W2 & 3.30 & 6.72 & 207.48 & 147.89 & 37.07 & 295.27 & 1105.55 & 36.79 & 500.94 & 65.00 \\
\hline W3 & 4.71 & 7.08 & 436.80 & 185.86 & 18.00 & 476.24 & 1927.20 & 118.86 & 689.70 & 47.40 \\
\hline W4 & 5.88 & 7.39 & 300.30 & 202.95 & 10.54 & 665.44 & 2230.53 & 0.00 & 419.82 & 0.00 \\
\hline W5 & 13.84 & 7.67 & 60.06 & 1146.69 & 10.54 & 1283.89 & 4893.56 & 82.07 & 755.04 & 137.69 \\
\hline
\end{tabular}

W1 - Calcium sulfate-rich water (CS); W2 - Magnesium chloride-rich water (MC $\mathrm{S}_{\mathrm{S1}}$; W3 - Calcium chloride-rich water (CC); W4 - Sodium chloride-rich water (SC); W5 - Magnesium chloride-rich water $\left(\mathrm{MC}_{\mathrm{S} 2}\right)$ 
In the harvest of Experiments I and II, which occurred at 79 and 90 DAS, respectively, plant height $(\mathrm{PH})$ and shoot diameter (SD) were measured with a graduated measuring tape $(\mathrm{cm})$ according to Gondim et al. (2011). Leaf area (LA) was also estimated using the disc methodology according to Pereira \& Machado (1987), and the number of leaves (NL) was counted. Shoot fresh mass (SFM) and shoot dry mass (SDM) were also obtained with a precision scale $(0.001 \mathrm{~g})$, by weighing immediately after harvest and after the plant material reached constant weight when dried in a forced ventilation oven, respectively.

The data obtained were subjected to analysis of variance by $\mathrm{F}$ test and, when there were significant effects, regression analysis was performed and the means were compared by Tukey test at $\mathrm{p} \leq 0.05$. The models were selected based on the significance of the regression coefficients, highest coefficient of determination and biological explanation.

\section{Results AND Discussion}

Figures 1 (Experiment I) and 2 (Experiment II) show the values of nutrient solution electrical conductivity (EC) throughout the crop cycle (49 DAT - Experiment I and 60 DAT - Experiment
II) as a function of the salinity levels of the waters used to prepare the nutrient solution and their flow rates of application.

The replacement of the evapotranspired depth promoted increase of ECsol in both experiments. However, in the nutrient solution prepared with public-supply water $\left(0.2 \mathrm{dS} \mathrm{m}^{-1}\right)$, there was a reduction in ECsol as a function of time at both flow rates (Figures 1A and B;2A and B), in response to the replacement of the evapotranspired depth with low-salinity water $\left(0.2 \mathrm{dS} \mathrm{m}^{-1}\right)$ because, as the plants absorbed the nutrients necessary for their development, there was a reduction in electrical conductivity. Results similar to those found in this study were reported by Soares et al. (2010), who worked with $7.46 \mathrm{dS} \mathrm{m}^{-1}$ salinity in the replacement of ETc with brackish water and found an increase in ECsol from 2.24 to $7.07 \mathrm{dS} \mathrm{m}^{-1}$ in 25 days of cultivation.

It was found that the pHsol values (Figures $1 \mathrm{C}$ and D; $2 \mathrm{C}$ and $\mathrm{D}$ ) remained within the range in which most nutrients are adequately available to plants, since $\mathrm{pH}$ variations within the range from 4.5 to 7.5 do not negatively affect most plants in hydroponic systems (Furlani et al., 1999).

According to the analysis of variance presented in Table 2, in Experiment I all studied variables were influenced by the single factors and their interaction.

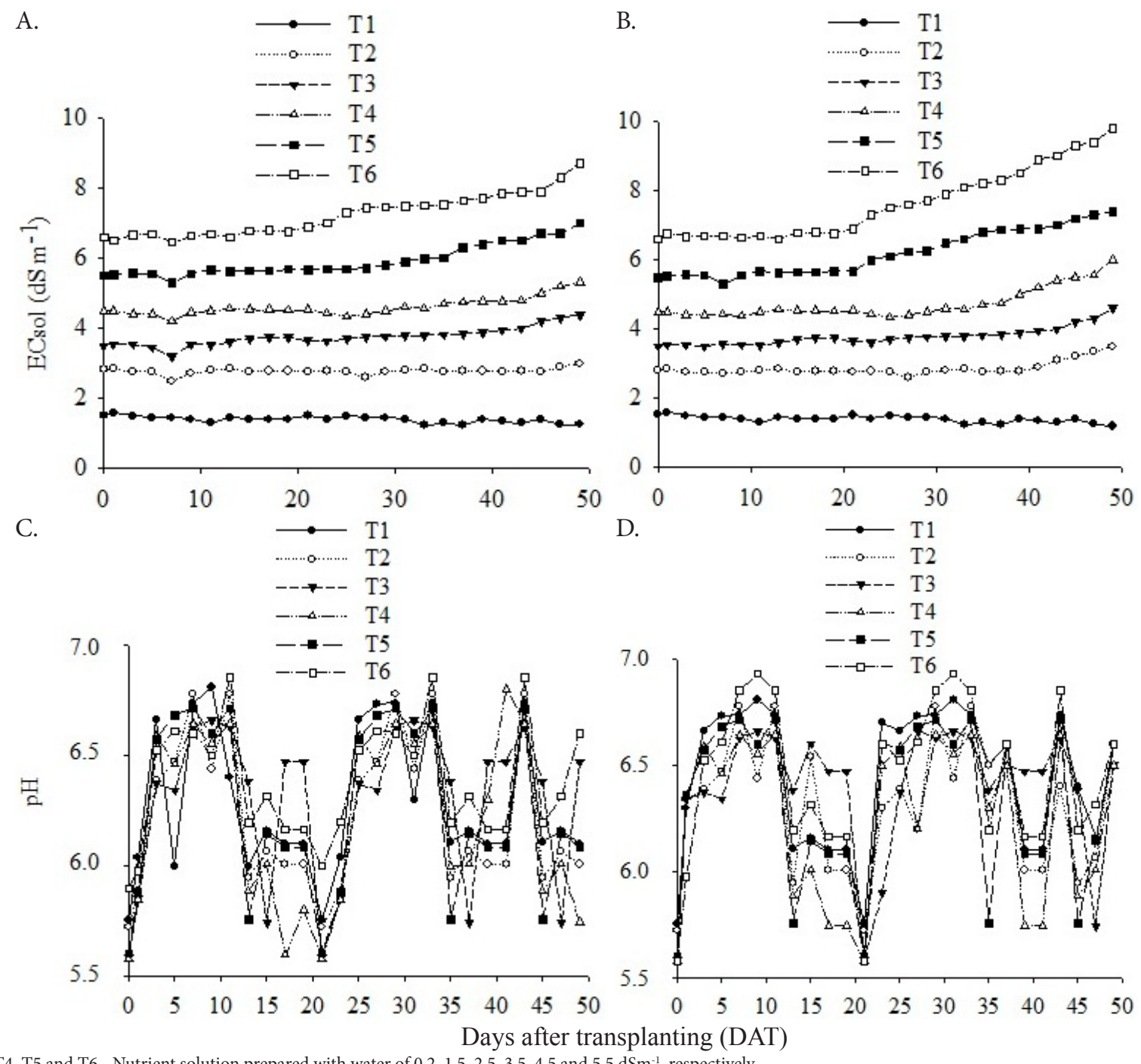

T1, T2, T3, T4, T5 and T6 - Nutrient solution prepared with water of $0.2,1.5,2.5,3.5,4.5$ and $5.5 \mathrm{dSm}^{-1}$, respectively

Figure 1. Mean values of the electrical conductivity of the solution - ECsol (A) and $\mathrm{pH}(\mathrm{C})$ of the nutrient solution at flow rate of $1.5 \mathrm{~L} \mathrm{~min}^{-1}$ and mean values of ECsol (B) and pH (D) of the nutrient solution at flow rate of $2.5 \mathrm{~L} \mathrm{~min}^{-1}$ along the cauliflower crop cycle in Experiment I 

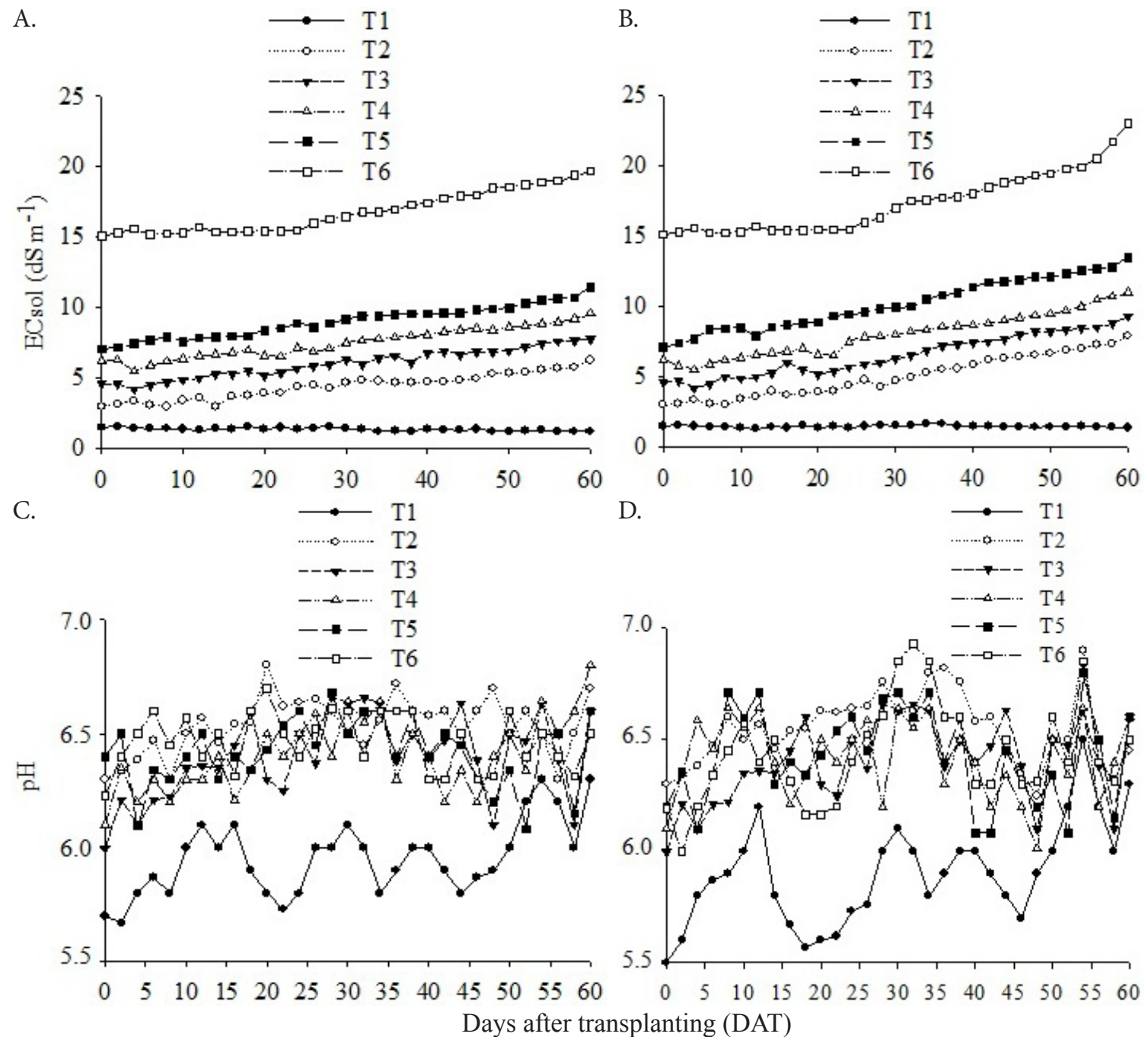

T1, T2, T3, T4, T5 and T6 - Nutrient solution prepared with water of $0.2,1.5,2.5,3.5,4.5$ and $5.5 \mathrm{dSm}^{-1}$, respectively

Figure 2. Mean values of ECsol (A) and pH (C) of the nutrient solution at flow rate of $1.5 \mathrm{~L} \mathrm{~min}^{-1}$ and mean values of ECsol (B) and $\mathrm{pH}(\mathrm{D})$ of the nutrient solution at flow rate of $2.5 \mathrm{~L} \mathrm{~min}^{-1}$ along the cauliflower crop cycle in Experiment II

Table 2. Summary of analysis of variance for the variables analyzed in cauliflower plants in Experiment I as a function of the electrical conductivity of the water $(\mathrm{ECW})$ used to prepare the nutrient solution and the flow rates of its application

\begin{tabular}{lccccccc}
\hline \multirow{2}{*}{ S. V. } & DF & \multicolumn{5}{c}{ Experiment I - Mean square } \\
\cline { 3 - 8 } & 5 & SFM & SDM & LA & NL & PH & SD \\
ECw & 5 & $257.4375^{* *}$ & $111.8497^{* *}$ & $70.6835^{* *}$ & $85.3881^{* *}$ & $95.6695^{* *}$ & $73.7824^{* *}$ \\
Flow rate & 1 & $58.3972^{* *}$ & $40.1536^{* *}$ & $54.2546^{* *}$ & $51.9552^{* *}$ & $96.8704^{* *}$ & $36.5643^{* *}$ \\
ECW x Flow rate & 5 & $4.6844^{* *}$ & $5.4186^{* *}$ & $8.2005^{* *}$ & $5.0299^{* *}$ & $9.9712^{* *}$ & $2.9022^{* *}$ \\
Residual & 36 & 509.45 & 8.17 & 166929.90 & 1.39 & 2.30 & 6.64 \\
CV (\%) & & 7.17 & 6.37 & 9.17 & 5.48 & 5.10 & 5.28 \\
\hline
\end{tabular}

S.V. - Source of variation; DF - Degrees of freedom; ${ }^{*}$ and ${ }^{* *}$ Significant at $p \leq 0.05$ and $p \leq 0.01$, respectively. SFM - Shoot fresh mass; SDM - Shoot dry mass; LA - Leaf area; NL Number of leaves; PH - Plant height; SD - Shoot diameter; ns - Not significant

The effect of salinity within the flow on plant biometrics was verified (Figure 3 ).

For the values of shoot fresh and dry mass and leaf area (Figures $3 \mathrm{~A}, \mathrm{~B}$ and $\mathrm{C})$, there was a reduction $(\mathrm{p} \leq 0.05)$ with the increase in $\mathrm{ECw}$, but the degree of this effect was variable according to the flow rate used. With the increase in the salinity of the water used to prepare the nutrient solution, there were linear reductions per unit increase in $\mathrm{ECw}$ of $11.0,7.0$ and $6.8 \%$ for SFM, SDM and LA at the flow rate of $1.5 \mathrm{~L} \mathrm{~min}^{-1}$, respectively. However, the use of flow rate of $2.5 \mathrm{~L} \mathrm{~min}^{-1}$ led to linear reductions per unit increase in ECw of 14.4, 10.4 and 12.6\% for the same variables.

Values on the order of $196.7 \mathrm{~g}, 36.7 \mathrm{~g}$ and $3824.6 \mathrm{~cm}^{2}$ were estimated for SFM, SDM and LA at the highest salinity $\left(5.5 \mathrm{dS} \mathrm{m}^{-1}\right)$ using the flow rate of $1.5 \mathrm{~L} \mathrm{~min}^{-1}$, results that are 47.5, 29.1 and $48.7 \%$ higher than those observed under flow rate of $2.5 \mathrm{~L} \mathrm{~min}^{-1}$, which led to estimated values on the order of $103.24 \mathrm{~g}$, $26.0 \mathrm{~g}$ and $1960.5 \mathrm{~cm}^{2}$ for SFM, SDM and LA, respectively.

The effect of flow rate was also variable according to the salinity of the water used to prepare the nutrient solution. Under low-salinity water $\left(0.2 \mathrm{dS} \mathrm{m}^{-1}\right)$, the highest values of SDM and LA occurred at the flow rate of $2.5 \mathrm{~L} \mathrm{~min}^{-1}(59.8 \mathrm{~g})$ and $\left(6239.5 \mathrm{~cm}^{2}\right)$, which are 1.1 and $3.39 \%$ higher than those observed with flow rate of $1.5 \mathrm{~L} \mathrm{~min}^{-1}, 59.1 \mathrm{~g}$ and $6034.7 \mathrm{~cm}^{2}$ for SDM and LA, respectively (Figures 3B and C).

Possibly, the bioaccumulation capacity of cauliflower based on the incorporation of compounds or ions associated with the 

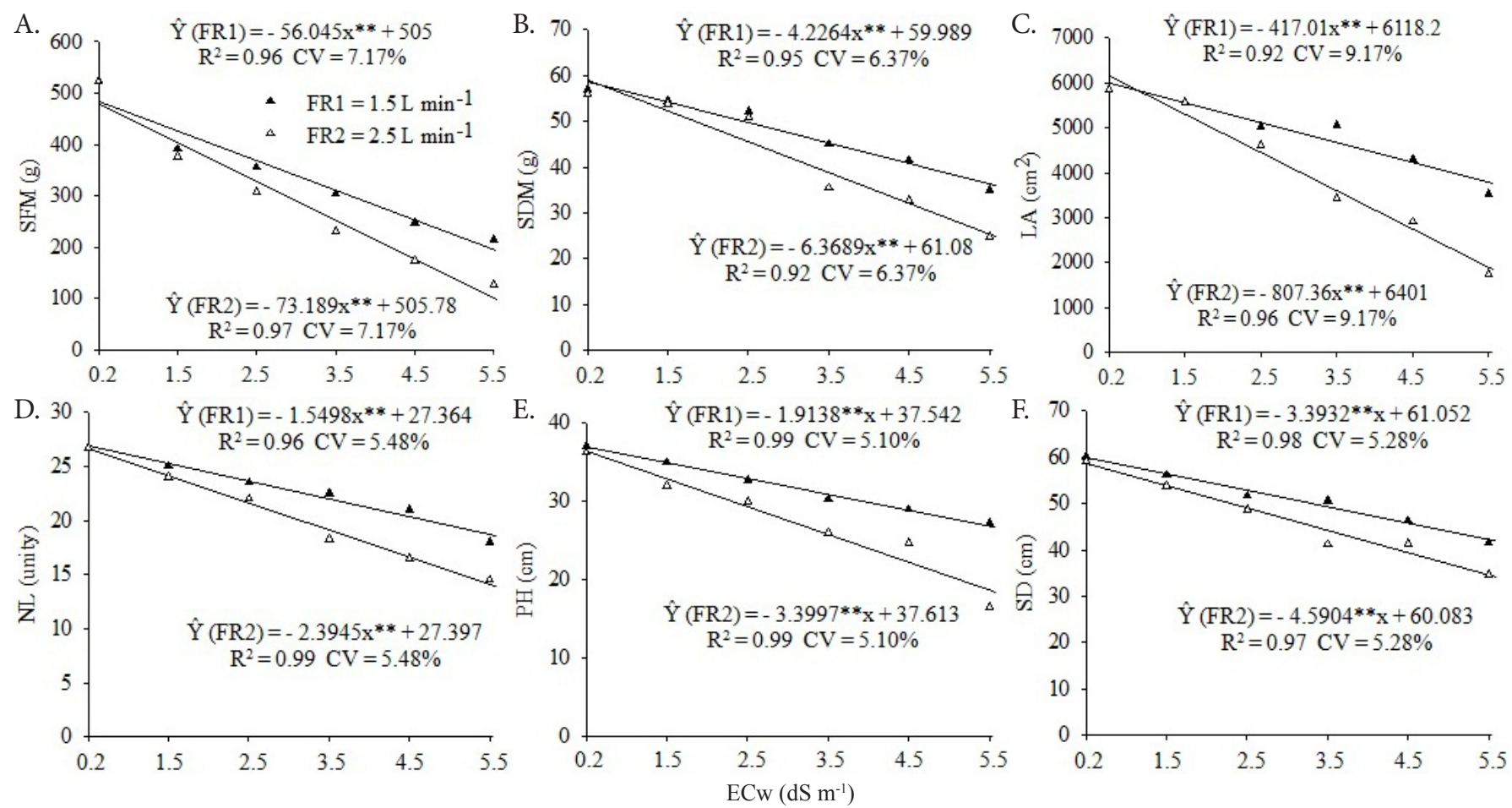

Significance at $\mathrm{p} \leq 0.01$ by F test

Figure 3. Shoot fresh mass - SFM (A), shoot dry mass - SDM (B), leaf area - LA (C), number of leaves - NL (D), plant height PH (E) and shoot diameter - SD (F) of cauliflower plants, cv. Piracicaba Precoce, as a function of the electrical conductivity of water $(\mathrm{ECW})$ applied at different flow rates (FR)

use of flow rate of $2.5 \mathrm{~L} \mathrm{~min}^{-1}$ with 3-m-long profiles reduced the absorption of water and nutrients, intensifying the effects of salinity on plant growth. The reduction of SDM with increasing salinity occurred due to the larger volume $(2.5 \mathrm{~L})$ of nutrient solution in contact with plant roots, compared to the smaller volume used $(1.5 \mathrm{~L})$, caused by mass flow in the rhizosphere of the crop, which explains the higher initial values of SDM in the control treatment.

According to Mendonça et al. (2017), the increase in flow rate leads to lower quantity of absorbed nutrients, consequently affecting the biometric responses of the plants, since the time of removal of the solute in the solution is not long enough for the ion to occupy all adsorption sites available.

The results obtained in this study, based on the analysis of SDM, at the lowest salinity level, are consistent with those found by Gondim et al. (2011), who evaluated the growth of cauliflower in NFT system (cv. Verona) and found values on the order of 87 g plant ${ }^{-1}$ at 70 DAT, under non-saline conditions. Reduction in leaf area represents an important adaptive mechanism because, besides reducing transpiration to conserve water in plant tissues, it also promotes a reduction in the transport of $\mathrm{Na}^{+}$and $\mathrm{Cl}^{-}$ions in the xylem (Taiz \& Zeiger, 2009). Reduction in leaf area as a function of increase in salinity has also been reported by Silva et al. (2008) and Oliveira et al. (2015).

Water salinity negatively affected NL, PH and SD. Linear reductions of 5.6, 5.0 and 5.5\% per unit increase in ECw (Figures $3 \mathrm{D}, \mathrm{E}$ and $\mathrm{F}$ ) were found at the flow rate of $1.5 \mathrm{~L} \mathrm{~min}^{-1}$, while the use of flow rate of $2.5 \mathrm{~L} \mathrm{~min}^{-1}$ led to linear reductions of 8.7, 9.0 and $7.6 \%$ per unit increment in $\mathrm{ECw}$ for the same variables evaluated. There were values on the order of 19 units for NL, $27.0 \mathrm{~cm}$ for $\mathrm{PH}$ and $42.3 \mathrm{~cm}$ for SD at the highest salinity $(5.5$ $\mathrm{dS} \mathrm{m} \mathrm{m}^{-1}$ ) using the flow rate of $1.5 \mathrm{~L} \mathrm{~min}^{-1}$, results that are 26.3,
30 and $17.7 \%$ higher than those obtained under flow rate of 2.5 $\mathrm{L} \mathrm{min}^{-1}$, which resulted in estimated values on the order of 14 units for NF, $18.9 \mathrm{~cm}$ for $\mathrm{PH}$ and $34.8 \mathrm{~cm}$ for SD, respectively.

Reduction of biometric variables in cauliflower plants in hydroponic cultivation using brackish waters was also reported by Giuffrida et al. (2016), who evaluated the effects of salinity during two growth stages on cauliflower production and quality, but working with salinity of up to $4.0 \mathrm{dS} \mathrm{m} \mathrm{m}^{-1}$. On the other hand, Lira et al. (2015) observed the same effects with ECsol levels of up to $5.2 \mathrm{dS} \mathrm{m}^{-1}$.

According to the analysis of variance presented in Table 3, it was found that in Experiment II, except for plant diameter, which was only influenced by the salinity of the water used to prepare the nutrient solution (ECw), the variables shoot fresh mass, shoot dry mass, leaf area, number of leaves and plant height were influenced by the single factors and their interaction (ECw x Flow rate).

The single-effect analysis of the significant interactions of the analysis of variance for Experiment II and the effect of ECw on SD are represented in Figure 4.

It was found that the increase in EC from 0.2 to $1.67 \mathrm{dS} \mathrm{m}^{-1}$ (W1), at the flow rate of $2.5 \mathrm{~L} \mathrm{~min}^{-1}$, led to reductions in fresh mass production (SFM) (Figure 4A) and dry mass production (SDM) (Figure 4B) of 18.4 and $10.4 \%$, respectively. At the flow rate of $1.5 \mathrm{~L} \mathrm{~min}^{-1}$, with the same increase in EC described above, there were reductions of 13.0 and $6.8 \%$ in SFM and SDM, respectively.

The reductions of SFM and SDM found in the present study are possibly due to the osmotic effect of nutrient solution salinity on the plants and to the excess of cations and anions, i.e. waters with different cationic natures described in Table 2 used to prepare this solution, since $\mathrm{Na}^{+}$and $\mathrm{Cl}^{-}$ions when in 
Table 3. Summary of analysis of variance for the variables shoot fresh mass (SFM), shoot dry mass (SDM), leaf area (LA), number of leaves (NL), plant height (PH) and shoot diameter (SD) in cauliflower plants, cv. Sarah 1169, exposed to nutrient solutions prepared and replaced with brackish waters analogous to waters from wells located in the Moxotó River Basin, municipality of Ibimirim, PE, Brazil, applied at different flow rates

\begin{tabular}{|c|c|c|c|c|c|c|c|}
\hline \multirow{2}{*}{ S. V. } & \multirow{2}{*}{ DF } & \multicolumn{6}{|c|}{ Experiment II - Mean square } \\
\hline & & SFM & SDM & LA & NL & PH & SD \\
\hline ECw & 5 & $299.6505^{* *}$ & $1975.7371^{\star *}$ & $4681.3275^{\star \star}$ & $135.364^{\star *}$ & $57.8132^{\star *}$ & $3.7181^{* *}$ \\
\hline Flow rate & 1 & $32.3299^{\star *}$ & $203.6644^{\star \star}$ & $393.5146^{\star \star}$ & $98.352^{* *}$ & $63.4287^{\star *}$ & $0.7097^{\text {ns }}$ \\
\hline ECw $x$ Flow rate & 5 & $3.8926^{\star *}$ & $28.7386^{\star \star}$ & $41.1871^{\star \star}$ & $11.801^{\star *}$ & $6.9774^{\star \star}$ & $1.1638^{\text {ns }}$ \\
\hline Residual & 36 & 3671.63 & 3.05 & 6994.23 & 1.99 & 20.38 & 187.86 \\
\hline CV (\%) & & 8.82 & 2.47 & 2.38 & 5.29 & 8.89 & 16.56 \\
\hline
\end{tabular}
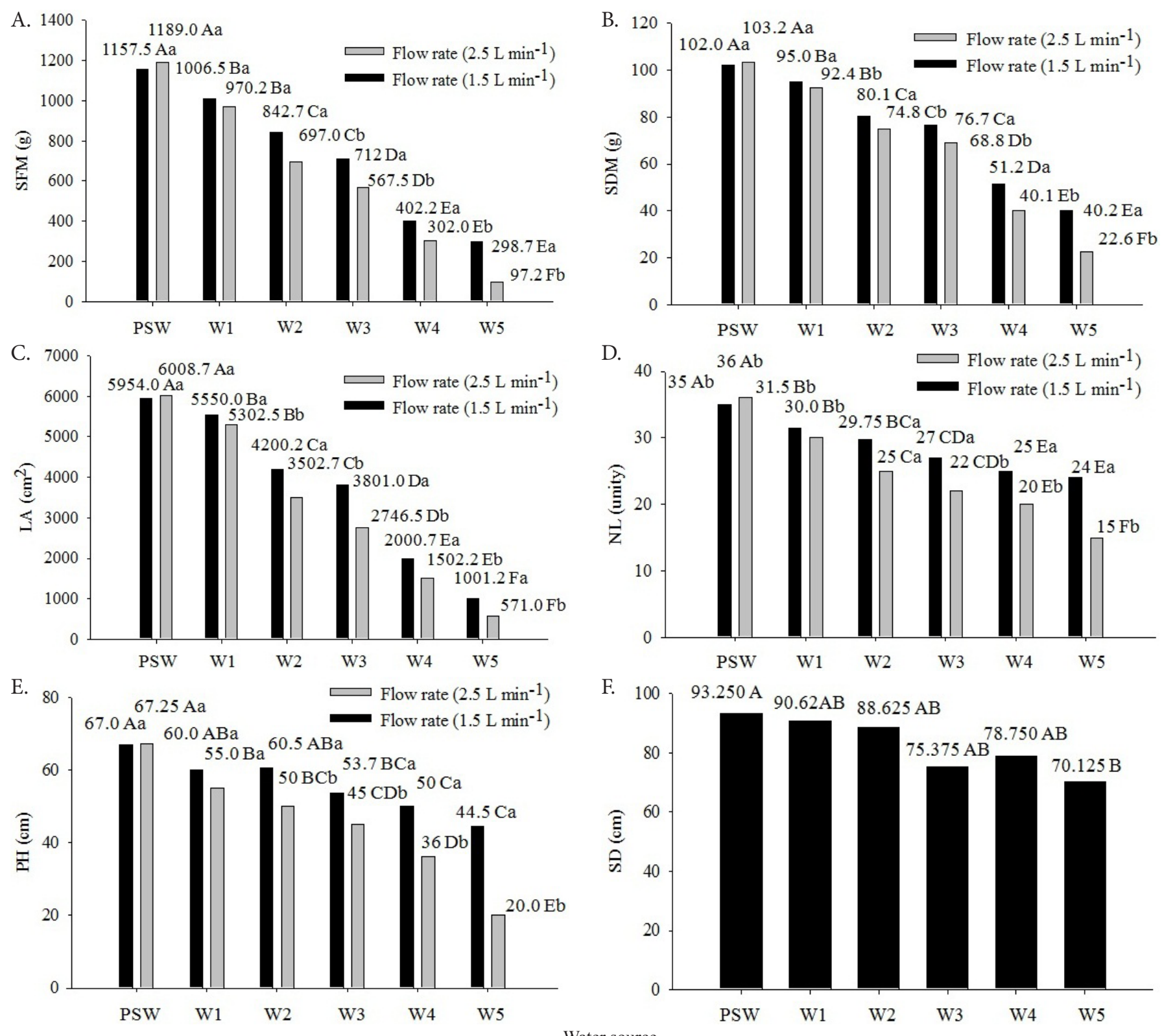

Water source

PSW - Public supply water (conmtrol); W1 - Calcium sulfate-rich water (CS); W2 - Magnesium chloride-rich water (MC ); W3 - Calcium chloride-rich water (CC); W4 - Sodium chloride-rich water (SC); W5 - Magnesium chloride-rich water $\left(\mathrm{MC}_{\mathrm{S} 2}\right)$; Means followed by the same letters do not differ by Tuckey test at $\mathrm{p} \leq 0.05$ (uppercase letters correspond to salinity levels and lowercase letters to flow rates)

Figure 4. Shoot fresh mass - SFM (A), shoot dry mass - SDM (B), leaf area - LA (C), number of leaves - NL (D), plant height $\mathrm{PH}(\mathrm{E})$ and shoot diameter - SD (F) of cauliflower, as a function of the use of simulated brackish waters and flow rates

excess can cause imbalance in the absorption of nutrients that are essential to plants, such as K and Ca (Abbasi et al., 2016).

Reduction of growth as a function of the cationic nature was also observed by Aghajanzadeh et al. (2017), who studied the effect of different types of salts on glucosinolate contents and composition of Brassica rapa seedlings and observed variable response depending on the type of salts $\left(\mathrm{NaCl}, \mathrm{KCl}, \mathrm{Na}_{2} \mathrm{SO}_{4}\right.$ and $\mathrm{K}_{2} \mathrm{SO}_{4}$ ) and part of the plant.

The highest values of leaf area (Figure 4C), number of leaves (Figure 4D) and plant height (Figure 4E), at the two 
flow rates of nutrient solution application $\left(1.5\right.$ and $\left.2.5 \mathrm{~L} \mathrm{~min}^{-1}\right)$, were obtained with the control treatment (PSW). However, a comparison of only the waters from the wells for each flow rate showed that, as observed for SFM and SDM, the waters from the well W5, with $\mathrm{EC}=13.84 \mathrm{dS} \mathrm{m}^{-1}$, also led to the lowest values of leaf area, number of leaves and plant height.

Shoot diameter was influenced by the single effect $(\mathrm{p} \leq 0.01)$ of the source of variation water salinity $(\mathrm{ECw})$. The means of SD when using public-supply water $\left(0.2 \mathrm{dS} \mathrm{m}^{-1}\right)$ differed only from the means obtained with magnesium chloride-rich water $\left(\mathrm{MC}_{\mathrm{S} 2}\right)$, and with the use of these waters there was lower SD per plant $(70.1 \mathrm{~cm})$. The use of the other brackish waters did not differ statistically according to the Tukey test at $\mathrm{p} \leq 0.05$ (Figure $4 \mathrm{~F}$ ).

As there was significant effect of waters with different natures and salt concentrations on the variables LA and NL at both flow rates $\left(1.5\right.$ and $\left.2.5 \mathrm{~L} \mathrm{~min}^{-1}\right)$, it is inferred that plants reduced their SFM by reducing both the size and number of leaves. The number of leaves is a genetic trait, varying according to the development of the plant. Reduction of leaf area is a mechanism of plant survival that enables the conservation of water due to the smaller transpiration area, contributing to the adaptation of crops to the saline conditions.

The ratio between bicarbonate and chloride concentrations is important to evaluate the quality of the brackish waters as well as the impact on the biometric parameters of plants, given the effects of these anions on the nutrient solution. In the present study, it can be observed that the $\mathrm{HCO}_{3} / \mathrm{Cl}^{-}$ratio in the simulated brackish waters from the different wells located in the Moxotó River Basin decreased as salinity increased. Values of $1.03,0.45,0.35,0.18$ and $0.15 \mathrm{mg} \mathrm{L}^{-1}$ were found for this ratio in the waters from $\mathrm{W} 1, \mathrm{~W} 2, \mathrm{~W} 3, \mathrm{~W} 4$ and $\mathrm{W} 5$, respectively (Table $1)$. The results obtained in the present study corroborate those obtained by Maia et al. (2012), who evaluated the ratio between bicarbonate and chloride in waters from wells of northeastern Brazil for irrigation purposes.

When well waters were compared only with one another, it was found that for the other variables evaluated the best flow rate of nutrient solution application was $1.5 \mathrm{~L} \mathrm{~min}^{-1}$ (Figure 4). At flow rate of $2.5 \mathrm{~L} \mathrm{~min}^{-1}$ using magnesium chloride-rich water $\left(\mathrm{MC}_{\mathrm{S} 2}\right)$ with $\mathrm{EC}=13.84 \mathrm{dS} \mathrm{m}^{-1}$, it was observed that plant growth for the evaluated parameters was drastically affected to the point of reducing cauliflower growth (Figure 4 ), which is attributed to the accumulation of salts over time and, consequently, the lower absorption of nutrients by plants.

The higher concentrations of $\mathrm{CO}_{3}{ }^{2-}$ and $\mathrm{HCO}_{3}{ }^{-}$in the brackish waters possibly contributed to the precipitation of ions. Symptoms such as stunting and leaf discoloration were observed in plants subjected to nutrient solutions with these anions. Similar results were found by Silva et al. (2018) evaluating the use of brackish waters from underground wells with different natures and concentrations in the semiarid region of Bahia, Brazil, in NFT hydroponic cultivation.

The results show that, when using waters with the same chemical composition as those found in the wells $\mathrm{W} 1$, calcium sulfate-rich water (CS) with EC $=1.67 \mathrm{dS} \mathrm{m}^{-1}$, and $\mathrm{W} 2$, magnesium chloride-rich water $\left(\mathrm{MC}_{\mathrm{S} 1}\right)$ with $\mathrm{CE}=3.30$ $\mathrm{dS} \mathrm{m}^{-1}$, to prepare the nutrient solution and replace the evapotranspired depth at the flow rate of $2.5 \mathrm{~L} \mathrm{~min}^{-1}$, the producer will have lower yield losses in cauliflower, compared to the use of waters from the wells W4, sodium chloride-rich water (SC), and $\mathrm{W} 5$, magnesium chloride-rich water $\left(\mathrm{MC}_{\mathrm{S} 2}\right)$, since the excess of sulfate, carbonate and bicarbonate present in these waters can precipitate calcium, for example, reducing its availability, which in turn affects plant growth.

\section{Conclusions}

1. Increase in the salinity of the water used to prepare the nutrient solution and replace the evapotranspired depth reduced cauliflower growth variables.

2. Nutrient solution flow rate of $1.5 \mathrm{~L} \mathrm{~min}^{-1}$ was the one that promoted the best results in both experiments for the growth variables analyzed, compared to $2.5 \mathrm{~L} \mathrm{~min}^{-1}$.

3. The best water for cauliflower cultivation was publicsupply water and, among well waters, the best was calcium sulfate-rich water (CS) with EC of $1.67 \mathrm{dS} \mathrm{m}^{-1}$ and the inappropriate one was magnesium chloride-rich water $\left(\mathrm{MC}_{\mathrm{S} 2}\right)$ with EC of $13.84 \mathrm{dS} \mathrm{m}^{-1}$.

\section{Literature Cited}

Abbasi, H.; Jamil, M.; Haq, A.; Ali, S.; Ahmad, R.; Malik, Z.; Parveen, D. Salt stress manifestation on plants, mechanism of salt tolerance and potassium role in alleviating it: A review. ZemdirbysteAgriculture, v.103, p.229-238, 2016. https://doi.org/10.13080/ z-a.2016.103.030

Aghajanzadeh, T. A.; Reich, M.; Kopriva, S.; Kok, L. J. de. Impact of chloride $(\mathrm{NaCl}, \mathrm{KCl})$ and sulphate $\left(\mathrm{Na}_{2} \mathrm{SO}_{4}, \mathrm{~K}_{2} \mathrm{SO}_{4}\right)$ salinity on glucosinolate metabolism in Brassica rapa. Journal of Agronomy and Crop Science, v.204, p.137-146, 2017. https://doi.org/10.1111/ jac. 12243

Bremenkamp, D. M.; Galon, K.; Hell, L. R.; Passos, G.; Cazaroti, E. P. F.; Cometti, N. N. Efeito da temperatura da solução nutritiva no crescimento da alface (Lactuca sativa L.) em hidroponia. Horticultura Brasileira, v.30, p.596-604, 2012.

Cruz, A. F. S.; Silva, G. F.; Silva, Ê. F. F.; Soares, H. R.; Santos, J. S. G.; Lira, R. M. Stress index, water potentials and leaf succulence in cauliflower cultivated hydroponically with brackish water. Revista Brasileira de Engenharia Agrícola e Ambiental, v.22, p.622-627, 2018. https://doi.org/10.1590/1807-1929/agriambi.v22n9p622-627

Furlani, P. R. Instruções para o cultivo de olerícolas de folhas pela técnica de hidroponia NFT. 1.ed. Campinas: Instituto Agronômico de Campinas, 1998. 30p. Boletim Técnico, 168.

Furlani, P. R.; Silveira, L. C. P.; Bolonhezi, D.; Faquin, V. Cultivo hidropônico de plantas. Campinas: Instituto Agronômico de Campinas, 1999. 52p. Boletim Técnico, 180.

Genuncio, G. C.; Silva, R. A. C.; Sá, N. M.; Mary, W.; Zonta, E. Produtividade de rúcula hidropônica cultivada em diferentes épocas e vazões de solução nutritiva. Horticultura Brasileira, v.29, p.605-608, 2011. https://doi.org/10.1590/S010205362011000400027

Giuffrida, F.; Cassaniti, C.; Malvuccio, A.; Leonardi, C. Effects of salt stress imposed during two growth phases on cauliflower production and quality. Journal of the Science of Food and Agriculture, v.97, p.1552-1560, 2016. https://doi.org/10.1002/ jsfa. 7900 
Gondim, A. R. O.; Prado, R. M.; Correia, M. A. R.; Alvez, A. U.; Cecílio Filho, A. B.; Politi, L. S. Curva de crescimento e acúmulo de matéria seca em couve-flor cultivada em substrato. Bioscience Journal, v.27, p.88-94, 2011.

Lira, R. M.; Silva, Ê. F. F.; Silva, G. F.; Santos, A. N.; Rolim, M. M. Production, water consumption and nutrient content of Chinese cabbage grown hydroponically in brackish water. Revista Ciência Agronômica, v.46, p.497-505, 2015. https://doi.org/10.5935/18066690.20150031

Lira, R. M.; Silva, Ê. F. F.; Silva, G. F.; Soares, H. R.; Willadino, L. G. Growth, water consumption and mineral composition of watercress under hydroponic system with brackish water. Horticultura Brasileira, v.36, p.13-19, 2018. https://doi. org/10.1590/s0102-053620180103

Maia. C. E.; Rodrigues, K. K. R. P.; Lacerda, V. S. Relação entre bicarbonato e cloreto em águas para fins de irrigação. Irriga, v.1, p. 206-219, 2012. https://doi.org/10.15809/irriga.2012v1n01p206

Mendonça, M. A.; Oliveira, R. A.; Duda, R. M.; Fujita, A. T.; Millan, R. N. Remoção de íons $\mathrm{Cu}^{2+}, \mathrm{Mn}^{2+}$ e $\mathrm{Zn}^{2+}$ em solução aquosa utilizando lodo biológico de reatores anaeróbios de alta taxa. Semina: Ciências Exatas e Tecnológicas, v.38, p.17-27, 2017. https://doi.org/10.5433/1679-0375.2017v38n2p17

Oliveira, F. A.; Martins, D. C.; Oliveira, M. K. T.; Souza Neta, M. L.; Ribeiro, M. S. S.; Silva, R. T. Desenvolvimento inicial de cultivares de abóboras e morangas submetidas ao estresse salino. Revista Agro@mbiente On-line, v.8,p.222-229, 2014.https://doi. org/10.18227/1982-8470ragro.v8i2.1540
Oliveira, F. A.; Silva, F. V. S.; Paiva, E. P.; Araújo, E. B. G.; Silva, M. K. N.; Andrade, R. A.; Moreira, R. C. L.; Souto, L. S. Emergência e crescimento inicial de plântulas de repolho cv. Chato de Quintal sob estresse salino. Agropecuária Técnica, v.36, p.273-279, 2015.

Pereira, A. R.; Machado, E. C. Análise quantitativa do crescimento de comunidade vegetais. Campinas: Instituto Agronômico de Campinas, 1987.33p. Boletim Técnico, 114

Silva, J. K. M.; Oliveira, F. A.; Maracajà, P. B.; Freitas, R. S.; Mesquita, L. X. Efeito da salinidade e adubos orgânicos no desenvolvimento da rúcula. Revista Caatinga, v.21, p.30-35, 2008.

Silva, J. S.; Paz. V. P. S.; Soares, T. M.; Almeida, W. F.; Fernandes, J. P. Produção de alface em sistema hidropônico NFT com águas salobras. Semina: Ciências Agrárias, v.39, p.947-962, 2018.

Soares, H. R.; Silva, Ê. F. de F. e; Silva, G. F. da; Pedrosa, E. M. R.; Rolim, M. M.; Santos, A. N. Lettuce growth and water consumption in NFT hydroponic system using brackish water. Revista Brasileira de Engenharia Agrícola e Ambiental, v.19, p.636-642, 2015. https:// doi.org/10.1590/1807-1929/agriambi.v19n7p636-642

Soares, T. M.; Duarte, S. N.; Silva, Ê. F. de F. e; Jorge, C. A. Combinação de águas doce e salobra para produção de alface hidropônica. Revista Brasileira de Engenharia Agrícola e Ambiental, v.14, p.705714, 2010. https://doi.org/10.1590/S1415-43662010000700004

Soares, T. M.; Duarte, S. N.; Silva, Ê. F. de F. e; Melo, R. F.; Jorge, C. A.; Oliveira, A. S. Experimental structure for evaluation of saline water use in lettuce hydroponic production. Irriga, v.14, p.102114, 2009. https://doi.org/10.15809/irriga.2009v14n1p102-114

Taiz, L.; Zeiger, E. Plant physiology. 3.ed. Porto Alegre: Artmed, 2009. 719p. 